\title{
$\mathrm{LCD}$ 패널을 탑재한 옥외 광고용 콘솔 개발에 관한 연구
}

\author{
최갑용 ${ }^{*}$ \\ ${ }^{1}$ 아주자동차대학 자동차계열
}

\section{A Study on the Development of the Console with LCD Panel for Exterior Advertizing}

\author{
Kab-Yong Choi ${ }^{1^{*}}$ \\ ${ }^{1}$ Division of Automobile, Ajou Motor College
}

요 약 본 연구의 목적은 Display 산업의 중요성에 주목하여 옥외 광고를 위한 LCD 패널용 콘솔(이하 'LCD 콘솔' 이라 한다.)을 개발하는데 있다. 본 연구의 핵심 과제는 LCD 콘솔의 내부온도를 제어할 수 있도록 해주는 냉각시스 템(Cooling System)을 개발하는 것이다. 냉각시스템은 상용화되어 있는 냉각휀(Cooling Fan), 히트싱크(Heat sinks), 열 전소자(Thermo Electronic Module) 등의 제품들을 시스템적으로 통합시키는 응용기술로서 통계적 검정기법을 적용하 여 개발되었다. 본 연구는 먼저 냉각시스템을 설계/제작한 후 실험을 통하여 냉각시스템 제어에 필요한 인자들의 설 정 값들을 구하는 과정을 보였다. 이어서 개발된 냉각시스템을 이용하여 46인치 LCD Panel이 탑재된 LCD 콘솔을 설계/제작하고 실험을 통하여 완성품 LCD 콘솔의 성능을 확인하는 과정을 보였다.

\begin{abstract}
The development of the console for exterior advertizing LCD Panel(LCD Console) is the purpose of this study with regard to importance of display industry. In this study, the most important point is to develop the cooling system for LCD Console. It is developed by using systematic application techniques and statistical tests and analysis to integrate commercial components, cooling fan, heat sink, thermo electronic modules etc, of it. This study, at first, shows design/manufacturing process of the cooling system and the setting process of control factors to control through experimentation. Next, after constructing the complete console, 46 inch LCD Panel and the cooling system are built in, the performance test of it is shown through experimentation.
\end{abstract}

Key Words : Console, LCD Panel, Heat Sink, Solid State Heat Pump, Cooling System,

\section{1. 서론}

\section{1 연구개요}

60년대에 주로 계산기나 손목시계용으로 제품화되기 시작한 LCD(Liquid Crystal Display)는 PC나 TV의 모니 터를 비롯하여 의료용, 자동차 및 항공 내비게이션시스템 용, 군사 및 방범용 등의 모니터링을 위한 디스플레이 장 치로 활용 영역이 확대되고 있다. 본 연구에서는 고차산 업의 소규모 지식전문 업체들의 옥외 영상광고에 이용할 수 있도록 LCD Panel을 채용한 광고용 콘솔(Console)을
개발하는데 목적을 두고 추진되었다. 지금까지 디스플레 이 패널을 이용한 상업용 옥외 영상광고 시스템은 고비 용으로 특수 제작되고 있기 때문에 소규모 지식전문 업 체들에게는 적합하지 않았다. 따라서 이에 부응하는 중규 모의 옥외광고용 영상시스템 개발이 필요한 시점에 와있 다. 국내·외적으로 $\mathrm{LCD}$ 를 이용한 옥외 광고시스템에 대한 연구와 제품개발이 활발히 진행되고 있기는 하지만 본 연구에서와 같이 특정한 계층을 대상으로 하는 '옥외 광고를 위한 LCD 패널용 콘솔’에 대한 연구는 초보단계 에 있다고 할 수 있다. 그 이유는 LCD 패널 제조에서 국 내기업이 세계를 선도하고 있기 때문이기도 하지만 본

본 논문은 아주자동차대학산학협력단과 (주)케이에스비가 2008년도 중소기업청이 지원하는 산학공동기술개발 연구과제로 수 행되었습니다.

"교신저자: 최갑용(kychoi@motor.ac.kr)

접수일 09년 09월 21일

수정일 (1차 09년 12월 08일, 2차 10년 01월 11일)

게재확정일 10 년 01 월 20 일 
연구가 철저한 마케팅 전략[2]에 따라 특수하게 분할된 틈새시장을 목표로 연구 과제를 채택하고 있기 때문이기 도 하다.

본 연구의 특징은 냉각시스템이나 콘솔과 같은 상위 시스템을 구성할 때 상용화되어있는 하위 제품들을 시스 템적으로 통합하는 결합기술을 이용하여 개발한다는 것 과 시스템을 구성하는 개별 부품들 간의 결합특성을 분 석할 때 통계적 검정기법을 이용하여 튜닝하고 성능을 검증한다는 것이다.

\section{2 연구의 필요성과 목적}

선행연구에 의한 경험에 따르면 초기의 콘솔이 가지고 있는 가장 큰 문제점은 시스템 작동 시에 여러 가지 원인 으로 인하여 내부온도가 과열된다는 것이다. 때문에 이를 해결하기 위하여 기계식 냉각시스템을 도입하였었으나 제작비를 비롯하여 중후장대(重厚長大), 소음과 유지보 수, 수명 등의 총체적인 문제가 발생함에 따라 이를 개선 할 필요성이 제기되었다. 따라서 본 연구의 목적은 경박 단소(輕薄短小)하면서 유지보수에 유리한 46인치 규모의 LCD Panel을 이용한 옥외광고용 콘솔을 개발하는데 있 다.

\section{2. 적용기술}

\section{1 적용기술의 개요}

본 장에서는 열전소자(Thermo Electronic Module, 이 하 TEM이라 한다.)를 이용한 열 교환 장치인 Solid State Heat Pump(이하 SSHP라 한다.), 냉각휀(Cooling Fan), 히 트싱크(Heat Sinks), 히트파이프(Heat Pipe) 등을 시스템 적인 결합을 통하여 ‘경박단소'하면서 유지보수에 용이 한 탈기계적인 냉각시스템을 개발하는 과정을 보이고자 한다. 따라서 본 냉각시스템의 연구는 구성요소가 가지고 있는 개별성능특성이나 물성과 같은 미시적인 문제보다 는 시스템적으로 결합하고 통합하는 응용기술에 의하여 이루어진다.

\subsection{Peltier 효과와 Solid State Heat Pump[2]}

냉각시스템의 핵심요소는 SSHP이다. SSHP를 구성하 는 열전재료는 Peltier효과에 의하여 그림 1 에서와 같이 재료의 양 끝에 온도차를 주었을 때 전압이 발생하고, 반 대로 직류전류를 통했을 때는 냉각 또는 가열되는 특성 을 갖는다. 열을 전기로, 전기를 열로 변환시킨다는 의미
에서 열전변환재료라고 부르기도 한다. TEM의 작동특성 은 $\mathrm{n}, \mathrm{p}$, type의 열전반도체를 전기적으로는 직렬, 열적으 로는 병렬로 연결하여 사용하도록 되어있다.

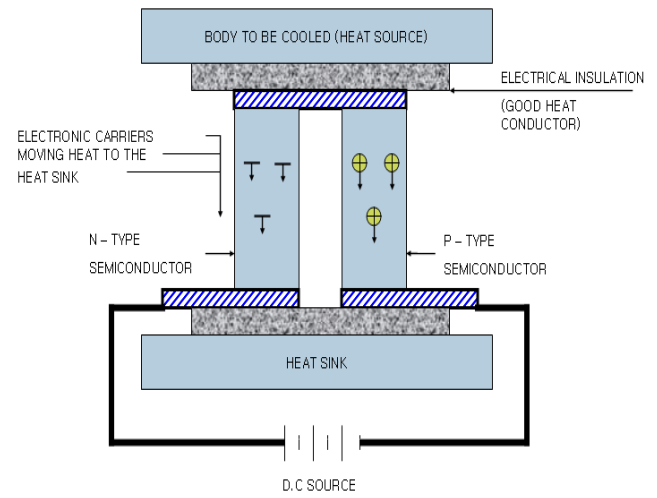

[그림 1] 열전소자의 단면도

\subsection{Solid State Heat Pump의 특성[1]}

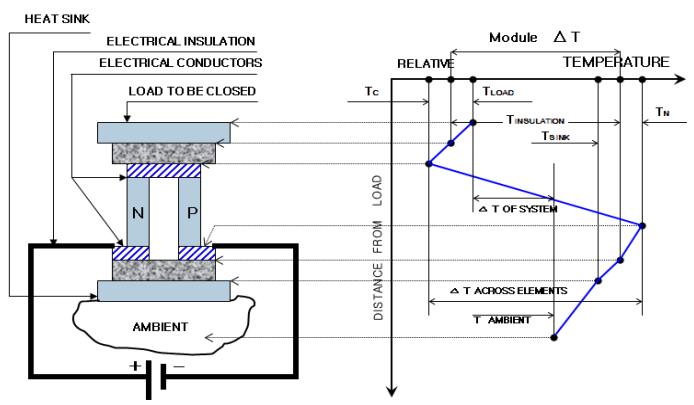

(A) Thermal Resistances

(B) Perfornancechar

[그림 2] 열전소자의 각 지점에 대응하는 부하거리에 대 한 상대온도차를 나타내는 성능특성도

본 연구/개발에서 사용하는 SSHP의 개념도는 그림 2 와 같다. 그림 2의 $(\mathrm{A})$ 는 열-전저항을 받는 $\mathrm{SSHP}$ 의 단면 구성을 나타내 것이고 $(\mathrm{B})$ 는 단면 구성요소의 각 국소에 서 발생하는 열-전량을 나타내는 성능곡선도표이다.

\section{LCD 콘솔용 냉각시스템 설계}

\subsection{LCD 콘솔의 내부온도 제어[3]}

그림 3은 본 연구에서 제안하는 LCD 콘솔용 내부온도 제어시스템의 블록선도이다. 


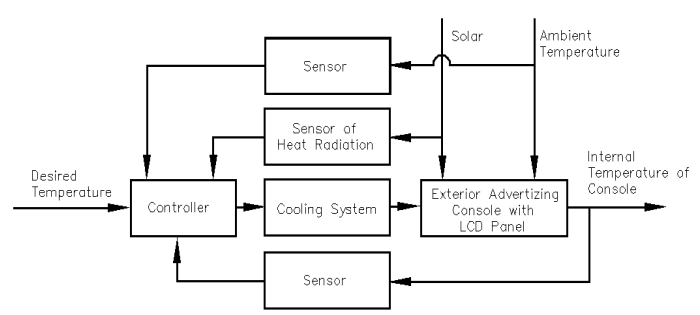

[그림 3] 콘솔 내부온도 제어시스템

콘솔 내부는 자체에서 발생하는 열과 태양광 또는 주 위의 여러 가지 원인으로 인하여 과도하게 온도가 상승 한다. 이를 제어하기 위하여 콘솔의 내부온도를 센서를 이용하여 실시간으로 감지해서 제어 값을 기준입력과 비 교한 후 제어기를 통하여 작동요소인 SSHP를 구동시킨 다. 이 때 흡열 측의 냉기는 히트싱크나 히트파이프를 통 하여 급속히 확산시킴과 동시에 휀을 이용하여 냉각된 공기를 콘솔의 상층부로 강제대류시킴으로서 콘솔의 내 부 온도를 제어한다. 본 연구에서는 L사의 PLC를 이용하 여 온도제어를 실시하였다. 제어모드로서는 비례제어기 만 사용하였다. 본 시스템의 특성상 안정성이 보다 더 개 선되어야 할 것으로 판단되었다. 그 이유는 실험의 결과 내부의 온도가 과도하게 상승하여 $90^{\circ} \mathrm{C}$ 에 이르기 때문이 다.

\subsection{Cooling System의 구성요소}

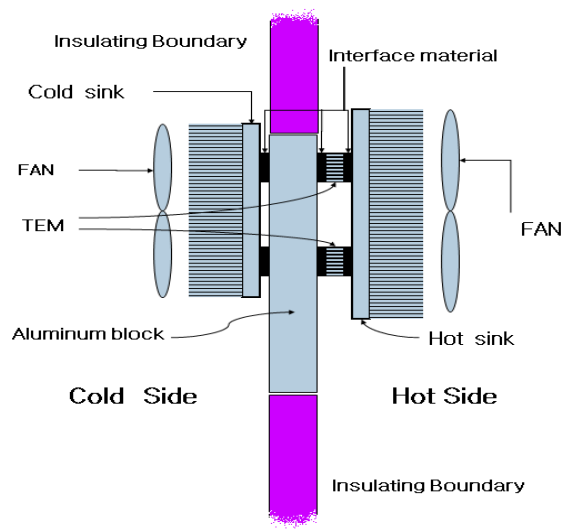

[그림 4] 냉각시스템 구성요소의 개념도

그림 4는 냉각시스템의 구성요소들 간의 결합을 보여 주는 개념도이다. 단위 $\mathrm{TEM}$ 의 냉각용량은 제한되어 있 기 때문에 시스템의 용량과 크기에 따라 중첩으로 TEM
을 결합하여 희망하는 성능을 얻도록 하였다. 이를 위해 서 그림 5 와 같이 일정 크기의 알루미늄 블록에 열전도율 이 높은 결합재로 쓰이는 열전도포재(Thermo Grease)를 이용하여 TEM과 히트싱크를 결합하였다. 단열경계 (Insulating Boundary)는 흡열측(Cold Side)과 방열측(Hot Side)의 열교란을 방지하는 역할을 한다.

히트싱크 표면의 냉/가열된 열은 자연대류에만 의존할 수 없기 때문에 냉각휀을 이용하여 강제대류 시킴으로써 속응성을 높이고 있다[9].

\section{3 냉각성능실험을 위한 장치의 설계/제작}

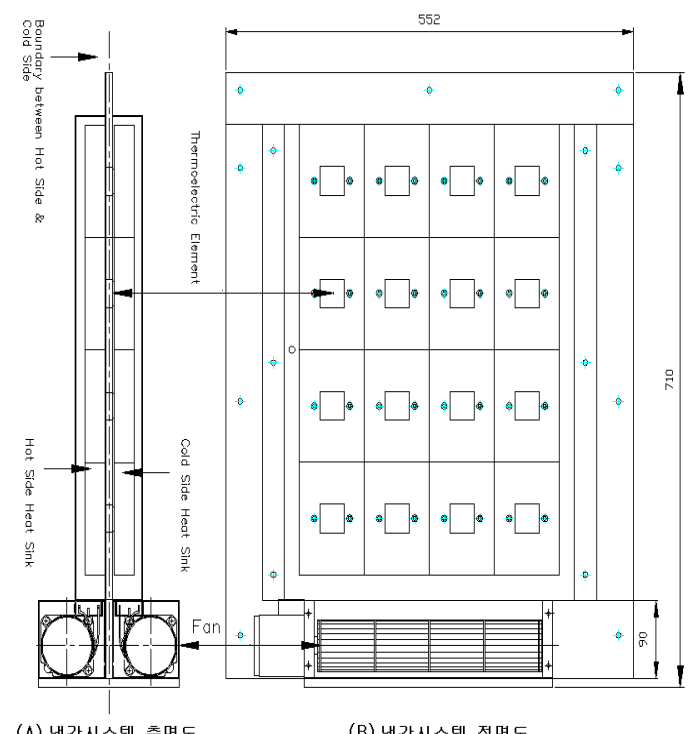

(A) 냉각시스템 측면도

(B) 냉각시스템 정면도

[그림 5] 냉각시스템의 구조와 열전소자의 배치

본 연구에서는 그림 5 와 같이 냉각시스템을 설계하였 다. 그리고 실험을 통하여 성능을 확인할 수 있도록 하기 위하여 그림 6 과 같이 제작하였다. 그림 6의 (A)는 조립 된 외관의 정면, $(\mathrm{B})$ 는 내부구조, $(\mathrm{C})$ 는 외관의 측면이 다.[10]

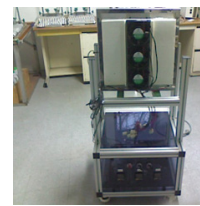

(A) 외관 정면

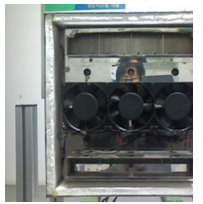

(B) 내부구조

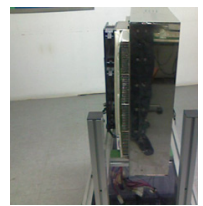

(C) 외관 측면
[그림 6] 냉각시스템의 성능실험장치 


\section{4. 작동특성 분석을 위한 실험}

\section{1 실험의 목적과 필요성}

냉각시스템의 적절한 용량설계와 성능향상을 위한 동 작특성을 결정하는 것은 매우 중요하다. $\mathrm{LCD}$ 콘솔용 냉 각시스템의 용량설계는 선행연구[2]에서 확인되었기 때 문에 본 연구에서는 이에 대한 검증은 생략키로 한다. 그 러나 시스템의 구조상 냉각휀의 설치 위치 때문에 휀의 작동방향에 따라 냉각효과에 영향을 미칠 수 있다는 문 제가 제기됨에 따라 이를 확인할 필요가 발생하였다. 따 라서 본 실험의 주된 목적은 그림 6 의 장치를 이용한 실 험을 통하여 이를 알아보는 것이다. 이를 위하여 실험계 획법에 따라 계획의 수립, 실험방법, 자료수집/정리를 실 시하고 검증절차에 따라 효과차이를 분석하였다.

\section{2 실험계획수립 및 실험방법설정과 검정}

\subsection{1 특성치의 선정과 실험의 배치}

본 실험의 인자는 표 1 과 같이 휀의 방향과 사용전력 으로 두 가지가 선택되었다.

[표 1] 요인별 효과와 실험조건

\begin{tabular}{|c|c|c|c|c|c|}
\hline Factors & Specification & Value[rpm] & \multicolumn{3}{|c|}{ Effects $\left[{ }^{\circ} \mathrm{C}\right]$} \\
\hline Direction & In Side & 1,800 & & 방 & \\
\hline of Fan & Out Side & 1,800 & Gं & 열 & \\
\hline Power & \multicolumn{5}{|c|}{$400(W)$} \\
\hline
\end{tabular}

사용전력은 표시인자로서 $400 \mathrm{~W}$ 로 고정시키고 주요인 자인 휀의 방향은 안쪽과 바깥쪽의 2 개 수준이 선택되었 다. 인자에 대한 효과는 흡열측과 방열측의 온도와 토출 온도 3 가지로 하였다. 실험에 앞서 표 2 와 같이 실험을 배치하였다.

[표 2] 실험의 배치

\begin{tabular}{|c|c|c|}
\hline & Cold Side FAN & Hot Side FAN \\
\hline Case 1 & In Side & In Side \\
\hline Case 2 & Out Side & Out Side \\
\hline Case 3 & In Side & Out Side \\
\hline
\end{tabular}

\subsection{2 실험 방법과 실시}

표 1 과 같이 요인별 효과와 실험조건을 설정하고 표 2 와 같이 실험을 배치한 후 실험을 실시하였다. 실험은 각 Case 마다 3회 실시하였으며 매 회 실시 때마다 비복원 무작위추출로 순서를 정하였다. 온도의 측정은 자동온도 측정 장치를 이용하여 5 분마다 측정하고 40 분 동안 8 회 측정하였으며 그 결과를 분석할 수 있도록 정리하였다.

\subsection{3 데이터 수집과 정리[8]}

[표 3] 성능실험 데이터

\begin{tabular}{|c|c|c|c|c|c|c|c|c|c|c|c|}
\hline \multicolumn{4}{|c|}{ CASE 1} & \multicolumn{4}{|c|}{ CASE 2} & \multicolumn{4}{|c|}{ CASE 3} \\
\hline $\begin{array}{l}\text { 시 } \\
\text { 간 } \\
\text { (분) }\end{array}$ & $\begin{array}{c}\text { 흡 } \\
\text { 열 } \\
\text { 측 } \\
\left({ }^{\circ} \mathrm{C}\right)\end{array}$ & $\begin{array}{c}\text { 방 } \\
\text { 열 } \\
\text { 측 } \\
\left({ }^{\circ} \mathrm{C}\right)\end{array}$ & $\begin{array}{c}\text { 토 } \\
\text { 출 } \\
\text { 온 } \\
\text { 도 } \\
\left({ }^{\circ} \mathrm{C}\right)\end{array}$ & $\begin{array}{l}\text { 시 } \\
\text { 간 } \\
\text { (분) }\end{array}$ & $\begin{array}{l}\text { 흡 } \\
\text { 열 } \\
\text { 측 } \\
\left({ }^{\circ} \mathrm{C}\right)\end{array}$ & $\begin{array}{c}\text { 방 } \\
\text { 열 } \\
\text { 측 } \\
\left({ }^{\circ} \mathrm{C}\right)\end{array}$ & $\begin{array}{c}\text { 토 } \\
\text { 출 } \\
\text { 온 } \\
\text { 도 } \\
\left({ }^{\circ} \mathrm{C}\right)\end{array}$ & $\begin{array}{c}\text { 시 } \\
\text { 간 } \\
\text { (분) }\end{array}$ & $\begin{array}{c}\text { 흡 } \\
\text { 열 } \\
\text { 측 } \\
\left({ }^{\circ} \mathrm{C}\right)\end{array}$ & $\begin{array}{c}\text { 방 } \\
\text { 열 } \\
\text { 측 } \\
\left({ }^{\circ} \mathrm{C}\right)\end{array}$ & $\begin{array}{c}\text { 토 } \\
\text { 출 } \\
\text { 온 } \\
\text { 도 } \\
\left({ }^{\circ} \mathrm{C}\right)\end{array}$ \\
\hline 0 & 17 & 17 & & 0 & & 20 & 20 & O & & & 20 \\
\hline 5 & 9 & 30 & 1 & & 1 & 31 & 14 & & 10 & 25 & 14 \\
\hline 10 & 10 & 3 & & & & 34 & & 0 & & 27 & 3 \\
\hline 15 & & & & & & 25 & & & & & 3 \\
\hline 20 & & 35 & & & 1 & 36 & 17 & 20 & & 28 & 13 \\
\hline 25 & 11 & 36 & 1 & 25 & 10 & 36 & 1 & 25 & & 29 & 13 \\
\hline 30 & 12 & 36 & & 30 & & 36 & & 30 & & 29 & 13 \\
\hline 35 & & 36 & & & 1 & 36 & & 35 & & 29 & 13 \\
\hline 40 & 11 & 36 & 13 & 40 & 10 & 36 & 13 & 40 & 9 & 29 & 13 \\
\hline
\end{tabular}
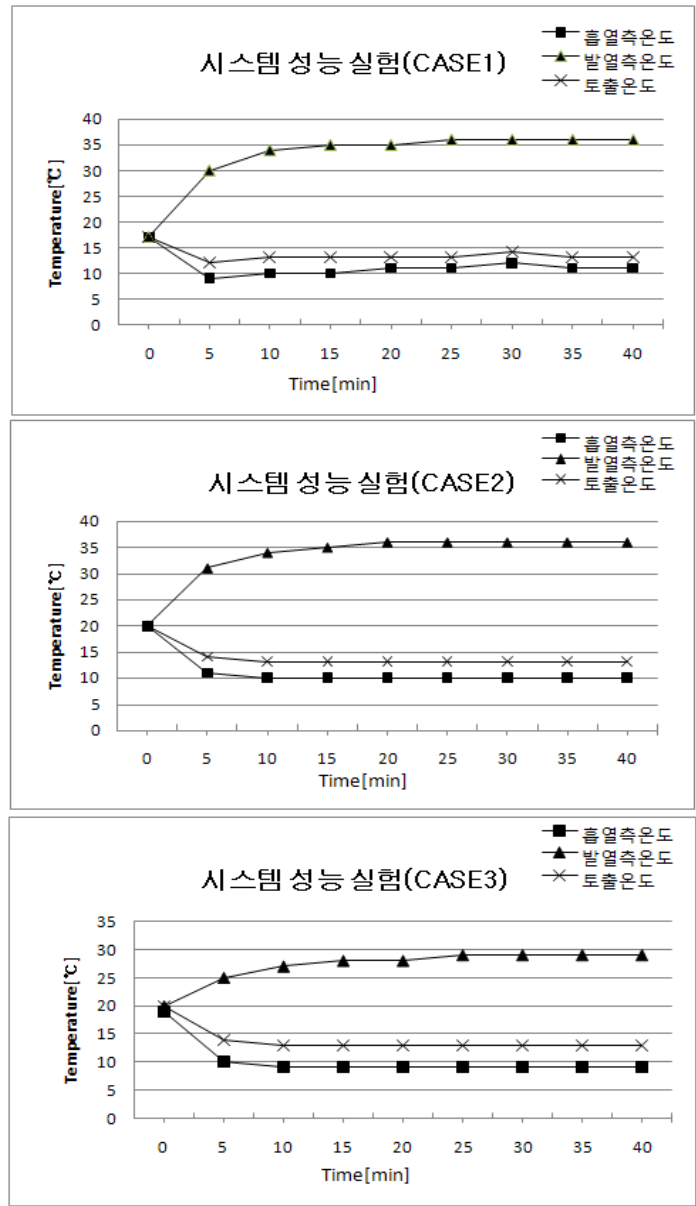

[그림 7] 냉각시스템의 성능실험 
표 2의 배치에 따라 실험을 실시하고 표 3 과 같은 결 과를 얻었다. 각 Case별로 5 분 간격으로 총 측정시간은 40 분 동안 3 회 실시하였으며 표 3 의 결과는 이들을 평균 한 값으로 보여주고 있다. 그림 7은 표 3의 결과를 Case 별로 도시한 것이다[4].

\section{3 실험결과 분석과 고찰}

\subsection{1 실험결과 분석}

표 3을 이용하여 각 Case별 성분들을 분석하고자 표 4 와 표 6 를 작성하였다. 표 4는 Case별 토출온도를 정리한 것이다. 토출온도는 제어대상 공정에서 측정된 것으로 제 어 값(Controlled Value)이다. 이 성분은 각 Case별 냉각 성능을 비교하는데 의미가 있다. 냉각성능은 정상상태에 도달하는데 걸리는 정정시간의 비교를 통하여 구별할 수 있다. 본 연구에서는 시간영역해석과 같은 전통적인 제어 이론의 적용보다 t-검정을 통하여 비교분석하였다.

[표 4] Case 별 토출온도(제어값)

\begin{tabular}{|c|c|c|c|}
\hline 시간(분) & $\operatorname{Case} 1\left({ }^{\circ} \mathrm{C}\right)$ & $\operatorname{Case} 2\left({ }^{\circ} \mathrm{C}\right)$ & $\operatorname{Case} 3\left({ }^{\circ} \mathrm{C}\right)$ \\
\hline 0 & 17 & 20 & 20 \\
\hline 5 & 12 & 14 & 14 \\
\hline 10 & 13 & 13 & 13 \\
\hline 15 & 13 & 13 & 13 \\
\hline 20 & 13 & 13 & 13 \\
\hline 25 & 13 & 13 & 13 \\
\hline 30 & 14 & 13 & 13 \\
\hline 35 & 13 & 13 & 13 \\
\hline 40 & 13 & 13 & 13 \\
\hline 평균 & 13.44444 & 13.88889 & 13.88889 \\
\hline
\end{tabular}

유의수준 0.05 에서 분석결과는 표 5 와 같다. P값이 유 의수준보다 크기 때문에 귀무가설이 채택됨에 따라 세 개의 Case에 대한 상호비교 결과 모두가 유의한 차이가 없다는 결과를 얻었다.

[표 5] 토출온도에 대한 분석결과

\begin{tabular}{|c|c|c|c|c|c|c|}
\hline \multirow{2}{*}{ 구분 } & \multicolumn{2}{|c|}{ Case1:Case2 } & \multicolumn{2}{c|}{ Case1:Case3 } & \multicolumn{2}{c|}{ Case2:Case3 } \\
\cline { 2 - 7 } & 변수 1 & 변수 2 & 변수 1 & 변수 2 & 변수 1 & 변수 2 \\
\hline 평균 & 21.44 & 22.11 & 21.44 & 16.88 & 22.11 & 16.88 \\
\hline 분산 & 66.27 & 72.61 & 66.27 & 38.11 & 72.61 & 38.11 \\
\hline 관측수 & 9 & 9 & 9 & 9 & 9 & 9 \\
\hline 자유도 & 8 & 8 & 8 & 8 & 8 & 8 \\
\hline F 비 & 0.91 & & 1.73 & & 1.90 & \\
\hline $\begin{array}{c}\mathrm{P}(\mathrm{F}<=f) \\
\text { 단측 검정 }\end{array}$ & 0.45 & & 0.22 & & 0.19 & \\
\hline $\begin{array}{c}\text { F 기각치: } \\
\text { 단측 검정 }\end{array}$ & 0.29 & & 3.43 & & 3.43 & \\
\hline
\end{tabular}

표 6의 방-흡열측 간 온도차에 대한 분석은 $\mathrm{SSHP}$ 의
성능을 비교하는데 의미를 갖는다. 그 이유는 SSHP의 입 력과 출력간의 관계는 그림 8 과 같이 수력펌프의 개념과 유사하기 때문에 수력펌프의 입구와 출구간의 수위차 즉 수두가 커지면 출구축의 압력이 증가하여 출력성능이 저 하되는데 마찬가지로 SSHP에서도 흡-방열측 간의 온도 차가 증가하면 성능에 좋지 않은 영향을 미친다고 볼 수 있다.

[표 6] Case 별 방-흡열측 간의 온도차이

\begin{tabular}{|c|c|c|c|}
\hline Time(분) & Case $1\left({ }^{\circ} \mathrm{C}\right)$ & Case $2\left({ }^{\circ} \mathrm{C}\right)$ & Case $3\left({ }^{\circ} \mathrm{C}\right)$ \\
\hline 0 & 0 & 0 & 1 \\
\hline 5 & 21 & 20 & 15 \\
\hline 10 & 24 & 24 & 18 \\
\hline 15 & 25 & 25 & 19 \\
\hline 20 & 24 & 26 & 19 \\
\hline 25 & 25 & 26 & 20 \\
\hline 30 & 24 & 26 & 20 \\
\hline 35 & 25 & 26 & 20 \\
\hline 40 & 25 & 26 & 20 \\
\hline 평균 & 21.44 & 22.11 & 16.89 \\
\hline
\end{tabular}

표 6의 분석결과는 유의수준 0.05 에서 Case1과 Case2 는 차이가 없고 Case1과 Case3, Case2와 Case3은 각각 유 의한 차이가 있다는 분석결과를 얻었다. 분석표는 지면제 약으로 생략키로 한다.

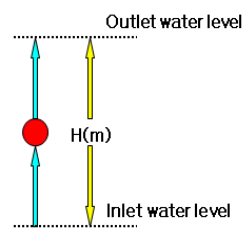

(A) Water Pump

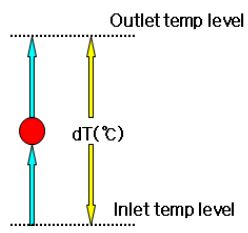

(B) Heat Pump
[그림 8] 수력펌프와 열펌프의 상사관계

\subsection{2 작통특성 분석을 위한 실험결과에 대한 고 찰}

본 실험은 냉각휀의 작동방향이 냉각시스템과 SSHP 의 성능에 영향을 미칠 수 있다는 문제제기에 따라 이를 규명코자 실시되었다. 이에 따라 실험계획을 수립하고 토 출온도 즉 제어값과 흡방열측간의 온도차를 인자로 설정 하여 효과를 측정하였다. 측정결과 각각의 경우에 대한 계측치들의 차이가 현저하지 않기 때문에 단순비교만으 로는 이들의 차이를 구분하는 것이 어렵다는 판단 하에 통계적 기법을 이용하여 검정을 통하여 분석하였다. 
냉각시스템의 성능분석에서는 세 개의 Case별로 각각 에 대하여 차이가 없는 것으로 분석결과 판정되었다. 이 것이 의미하는 것은 냉각시스템의 핵심요소인 SSHP의 용량이 제어 가능한 범위에 있다는 것을 반증한다고 할 수 있다. 따라서 용량에 관한 검증이 우회적인 반증되었 다고 할 수 있다. 흡-방열측 간의 온도차에 대한 분석에 서 냉각휀의 방향이 SSHP의 성능발휘에 유의한 차의 영 향을 미친다는 결과를 보임에 따라 '상대온도차가 낮을 수록 좋은 효과를 갖는다.'는 근거를 토대로 본 연구의 시스템에서는 Case3을 채택하였다.[6].

\section{LCD 콘솔의 설계/제작과 성능검증}

\subsection{LCD 콘솔의 설계와 구성요소 배치}

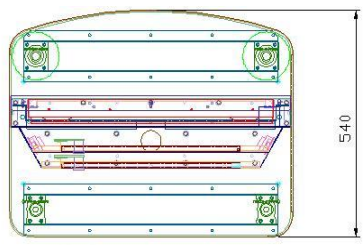

(C) 콘솔 평면도

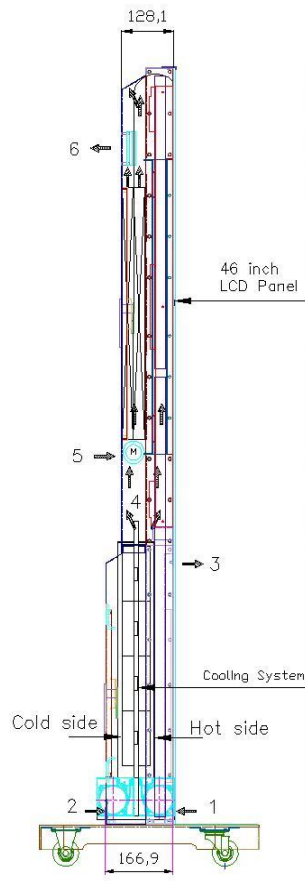

(B) 곤솔 우측면도

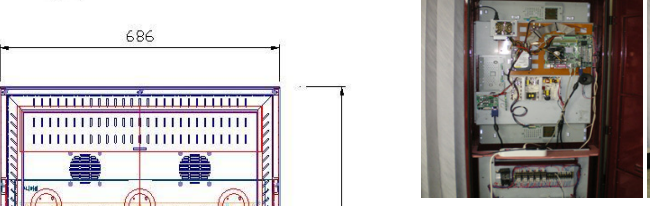

(A) 제어시스템

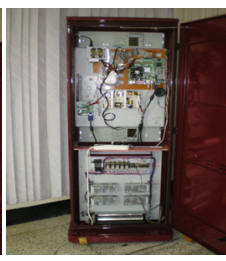

(B) 전체내부구조

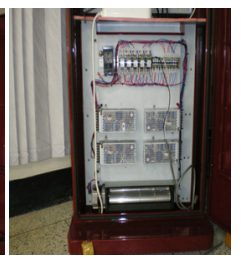

(C) 냉각시스템
[그림 10] LCD Panel용 콘솔의 완성품 내부

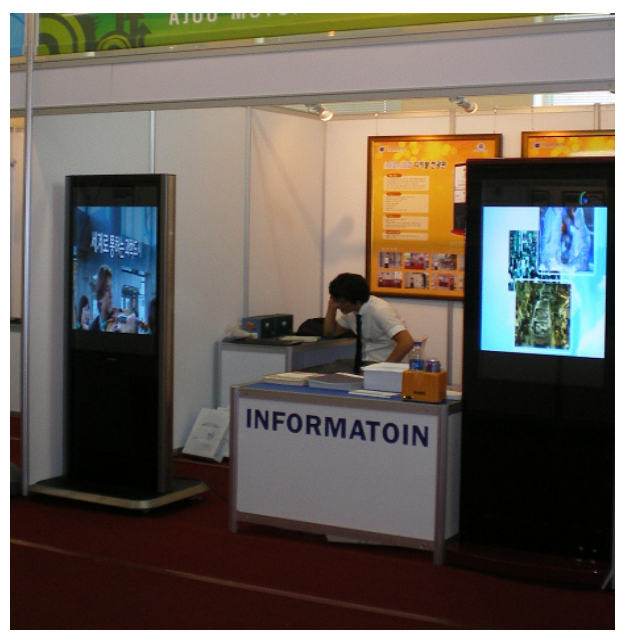

[그림 11] LCD Panel 콘솔 완성품 전시 사례

[그림 9] LCD 콘솔의 구조도 


\section{3 완성품의 성능검증을 위한 실험방법}

본 실험의 목적은 개발한 냉각시스템이 완성품 $\mathrm{LCD}$ 콘솔에 장착되었을 때 성능을 어느 정도로 발휘하는 지 를 알아보는 것이다. 이를 위하여 먼저 LCD Panel을 작 동시킨 상태에서 냉각시스템은 작동하지 않은 상태와 냉 각시스템을 작동했을 때의 추이를 비교함으로써 냉각시 스템의 성능과 효과를 확인해 보고자 한다.

\section{4 완성품 성능실험의 결과}

먼저 냉각시스템을 작동하지 않은 상태에서 $\mathrm{LCD}$ Panel을 켜고 콘솔 내부의 온도변화를 알아보았다. 모두 3 회에 걸쳐서 실시하였고 결과는 그림 12 와 같다. 이어서 냉각시스템을 작동한 상태에서 실험을 실시하였다. 본 실 험에서는 희망 값을 $31^{\circ} \mathrm{C}$ 로 설정하였다.[2] 3회에 걸쳐 실시하였고 결과는 그림 12 와 같이 모두 동일한 현상을 보였다[7].

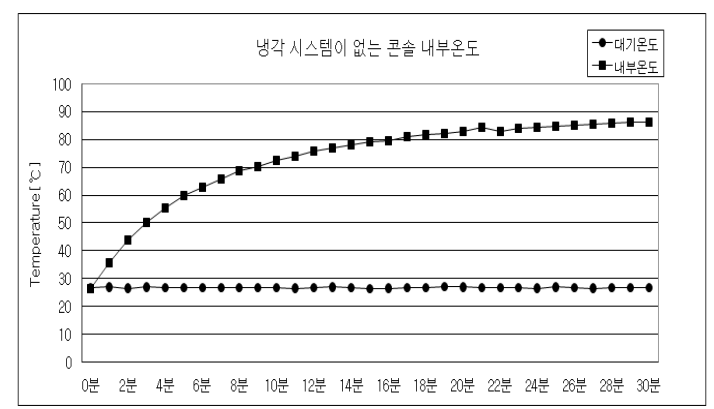

[그림 12] 냉각시스템을 작동하지 않은 완성품 LCD 콘 솔 내부온도의 시간별 추이

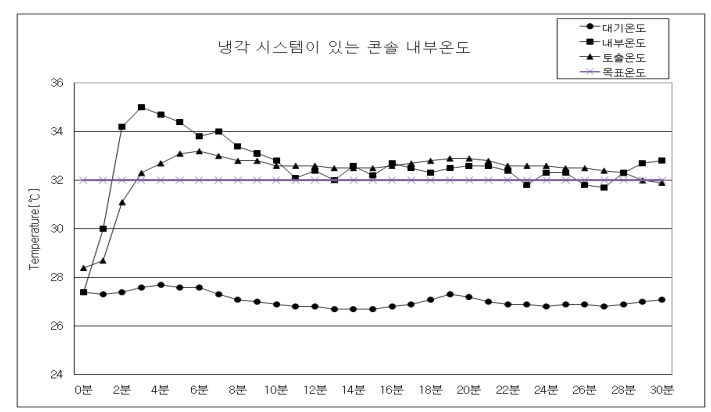

[그림 13] 냉각시스템을 작동한 완성품 LCD 콘솔 내부 온도의 시간별 추이

\section{5 완성품 성능 검증결과에 대한 고찰[5][8]}

본 연구에서는 먼저 냉각시스템을 개발하고 이어서 이
를 이용한 완성된 콘솔의 개발 순으로 이루어졌다. 완성 품 콘솔의 성능을 알아봄으로서 연구개발의 완성도를 높 이고자 완성품 성능검사를 위한 실험을 실시하여 그림 12 , 그림 13 과 같은 결과를 얻었다. 본 실험을 통하여 냉 각시스템의 성능과 그 중요성을 확인할 수 있었다. 냉각 시스템을 사용하지 않은 상태에서는 30 분 동안 작동하였 는데 $80^{\circ} \mathrm{C}$ 이상으로 내부온도가 상승하였고 꾸준히 온도 가 상승하여 불안정한 상태에 있음을 알 수 있다. 이러한 상태를 그대로 방치하게 되면 LCD Panel의 성능이나 수 명에 중대한 영향을 미칠 수 있기 때문에 냉각시스템의 사용이 필수가 된다. 냉각시스템을 작동한 실험에서는 전 형적인 귀환제어 특성을 보여주고 있다. 초기의 과도현상 에 이어 정정상태를 거쳐 정상상태에 도달한 후 지속적 으로 목표온도에 접근하고 있음을 보여주고 있다. 따라서 본 연구를 통하여 개발한 LCD 콘솔용 냉각시스템의 성 능은 적합한 것으로 판단한다.

\section{6. 결론}

본 연구를 통하여 얻은 결과를 정리하면 다음과 같다.

1. 개발제품의 사업화를 위한 제조설비 부담을 줄이고 빠른 시장적응성을 위하여 시스템을 통합하는 기술 의 전개과정을 보였다.

2. 시스템 통합기술로서 통계적 분석기법을 이용하여 냉각시스템의 성능특성 차이를 판별하고 최적의 조 건을 도출하는 과정을 보였다.

3. 흡방열측 간의 온도차에 대한 분석결과는 냉각휀 의 방향이 SSHP의 성능에 유의한 차의 영향을 미 친다는 것을 체계적인 실험과 검정과정을 통하여 입증하는 과정을 보였다.

4. 개발한 냉각기를 이용한 실험에서 $\mathrm{LCD}$ 콘솔의 제 어시스템이 초기의 과도현상을 거쳐 정상상태에 도 달한 후 목표입력에서 정정됨으로써 안정 상태를 성공적으로 유지하는 과정을 보였다.

이상의 연구결과에 이어 냉각시스템은 열악한 열적 악 조건 하에서 작동되기 때문에 보다 안정적인 제어가 이 루어 질 수 있도록 제어시스템의 로버스트성을 확보하는 후속 연구가 필요한 것으로 사료된다.

\section{참고문헌}

[1] 박경우 외, "핀-휜형 방열파의 설계 최적화", 설비공 학논문집, 제 15 권, 제10호, pp. 860-869, 1월, 2003. 
[2] 박종복, “디지털 전광판 $\mathrm{LCD}$ 판넬용 냉온시스템 개 발”, 중소기업청, 산학공동기술개발보고서, 7월, 2009.

[3] 장근선 외, “핀-튜브 열교환기와 알루미늄 열교환기 의 전열성능과 압력강화 특성비교", 산학기술학회 논 문지, 제10권, 제2호, pp. 222-229, 2월, 2009.

[4] R. Yun, "Evaluation of Performance of a Residental Air-Conditioning System Using Micro-Chanel and Fin-tube Heat Exchanger", Proceedings of the SAREK, pp. 28-35, 2007.

[5] 이영림 외, "대용량 알루미늄 브레이징 히트싱크 개 발에 관한 연구”, 산학기술학회 논문지, 제 10 권, 제7 호, pp. 1459-1464, 7월, 2009.

[6] 류지호, “ZMR-SOI 박막 결함에 미치는 이중열원 및 열전현상의 효과”, 서울대학금속공학과 박사학위논문, 8월, 1995.

[7] Donald R. Coughanowr,"Process Systems Analysys and Control”, McGRAW-HILL, pp.249-281, 2002.

[8] 박성현, “현대실험계획법”, 대영출판사, pp.115-140, 3 월, 2002년

[9] 구학근 외, “플레이트 휜 열교환기를 이용한 히트펌 프 시스템에 관한 실험적 연구”, 東明大學論文集, pp.489-496, 12. 2000.12),

[10] Young Chul Kwon ;Jeong-tae Kwon ;Ji Hwan Jeong ;Sang Jae Lee ;Dae Hun Kim "Performance of a 2 room multi-heat pump with a constant speed compressor", Society of Air-Conditioning and Refrigerating Engineers of Korea. vol.12 no.4 pp. 184-191, 12. 2004.

\section{최 갑 용(Kab-Yong Choi)}

[정회원]

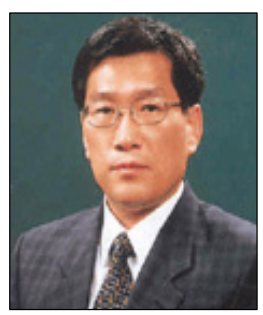

- 1989년 2월 : 숭실대학교 중소기 업대학원 졸업(공학석사)

- 1996년 8월 : 숭실대학교 대학원 졸업(공학박사)

- 1997년 3월 현재 : 아주자동 차대학 자동차계열 교수(자동차 개발전공, 금형전공)

<관심분야>

시스템 설계/제어, $\mathrm{CAD} / \mathrm{CAM} / \mathrm{CAE}$ 